\title{
ARBUSCULAR MYCORRHIZAL FUNGI ALLEVIATE THE TOXICITY OF CADMIUM INTERACTION AFFECTING THE GROWTH OF RYEGRASS (LOLIUM PERENNE L.)
}

\author{
SUN, M. L. ${ }^{1}-$ LI, T. ${ }^{1}-$ LI, D. M. ${ }^{1}-$ ZHAO, Y. L. ${ }^{1}-$ GAO, F. M. ${ }^{1}-$ SUN, L. F. ${ }^{1 *}-$ SUN, G. Y. ${ }^{2,3}$ \\ ${ }^{1}$ Crop Resources Institute of Heilongjiang Academy of Agricultural Sciences s, Harbin 150040, China \\ ${ }^{2}$ College of Life Science, Northeast Forest University, Harbin 150040, China \\ ${ }^{3}$ Key Laboratory of Saline-alkali Vegetation Ecology Restoration, Ministry of Education, Northeast \\ Forestry University, Harbin 150040, China \\ ${ }^{*}$ Corresponding author \\ e-mail: sunlianfa@aliyun.com; phone: 045186651186 \\ address: No.368 Xuefu Road, Harbin, Heilongjiang 150040, China
}

(Received 6 $6^{\text {th }}$ Oct 2020; accepted $21^{\text {st }}$ Dec 2020)

\begin{abstract}
A pot experiment was conducted to examine the effects of Glomus mosseae on some growth and physiological parameters, and cadmium (Cd) amounts in ryegrass (Lolium perenne L.) plants under the toxic levels of $\mathrm{Cd}$. The experiment was carried out with two treatments ( $G$. mosseae inoculation and non-inoculation), each having four $\mathrm{Cd}$ concentrations (0,30, 90 and $180 \mathrm{mg} \mathrm{Cd} \mathrm{kg}^{-1}$ soil). The results showed that mycorrhizal infection rate of G. mosseae was still as high as $43 \%$ under $180 \mathrm{mg} \mathrm{kg}^{-1} \mathrm{Cd}$ concentration, indicating that $G$. mosseae colonized plants were tolerant to $\mathrm{Cd}$ stress. In non-inoculated and inoculated plants, by increasing Cd concentration in the soil, growth parameters, root activity, growth index, biomass, $\mathrm{N}$ and $\mathrm{P}$ content in plant and photosynthetic characteristic were reduced. Root activity, growth index, biomass, $\mathrm{N}$ and $\mathrm{P}$ content, photosynthetic physiology, superoxide dismutase (SOD) and catalase (CAT) contents of G. mosseae inoculated plants were increased compared to non-inoculated plants, whereas malondialdehyde (MDA) content decreased to a certain extent. In conclusion, inoculation of $G$. mosseae enhanced the resistance and tolerance of ryegrass to $\mathrm{Cd}$ stress, reduced the damage of harmful substances to cells, and promoted its growth.
\end{abstract}

Keywords: Glomus mosseae, cadmium stress, plant growth, nutrition accumulation, photosynthetic characteristics

\section{Introduction}

In the natural ecosystem, $80 \%$ of all terrestrial plant species form symbiotic associations between arbuscular mycorrhiza fungi (AMF) and their roots (Smith and Read, 1997). The AMF obtain carbohydrates from the host plants. In return, the fungi benefit their host plants principally by enriching nutrition uptake, enhancing resistance to pathogens (Pozo et al., 2002), improving tolerance to drought stress (Augé et al., 1994) and improving soil structure (Rillig and Steinberg, 2002). In addition, AM symbiosis has been shown to take an active part in plant resistance to heavy metal contamination including $\mathrm{Zn}, \mathrm{Pb}, \mathrm{Cu}, \mathrm{Cr}$ and Cd (Shetty et al., 1995; Díaz et al., 1996; Davies et al., 2001; Chen et al., 2007; Shahabivand et al., 2012). For example, Vodnik (2008) demonstrated that AM symbiosis can prevent plant from absorbing heavy metal by secreting some organic compounds in soils to chelate metal ions. Gonzalez-Chavez (2002) have investigated that AM fungi colonized in $H$. lanatus carried out their role by aiding the host to fix toxic metals within the rhizospheric zone, thereby preventing the uptake of toxic metals into the plant (Gonzalez-Chavez et al., 2010). 
In recent years, heavy metals released to soils bring about irreversible soil degradation and hence severely limit vegetation establishment, which mainly resulted from human activities (Shukurov et al., 2005; Rajkumar et al., 2012). Cadmium (Cd) is non-essential heavy metal element for plant growth with phytotoxicity even at very low concentration$0.5 \mathrm{mg} \mathrm{kg}{ }^{-1}$ (Yong et al., 2009). Cd enters the aquatic environment from natural (weathering of rocks) as well as anthropogenic sources (industrial effluents, agricultural run offs) (Schützendübel et al., 2002). The presence of an excessive amount of $\mathrm{Cd}$ causes an inhibition of enzyme activities, water imbalance and alterations of membrane permeability in plants (Y1lmaz and Parlak, 2011). It exerts an adverse effect on seed germination (Peralta et al., 2001), morphology, growth and the photosynthetic processes in plants, even leading to plant death (Zorrig et al., 2013; Hassan and Mansoor, 2014; Asgher et al., 2015). Improper discharge of Cd into environment has resulted in severe contaminations, and subsequently threatened the environmental quality and human health over the long-term (Kirkham, 2006; Ali et al., 2013).

Mycorrhizal fungi have been found to influence $\mathrm{Cd}$ uptake and accumulation in plants with changes in its immobilization and mobilization in Cd-polluted soils (Chen et al., 2004b). Investigations indicated that many plant species, such as Fragaria vesca, Viola calaminaria, Veronica rechingeri, Thymus polytrichus and Lolium perenne, growing well at natural heavy metal polluted sites and all of them were colonized by AMF (Turnau et al., 2001; Whitfield et al., 2004; Zarei et al., 2008a; Alguacil et al., 2011). Ryegrass (Lolium perenne L.) was used as a model plant because of its rapid growth, tolerance to various environments, soil types and its common use in phytoremediation studies (Arienzo et al., 2004; Meng et al., 2011). The objectives of our experiment were to investigate the efficiency of AMF application into different $\mathrm{Cd}$-added soils $(0,30,90$ and $180 \mathrm{mg} \mathrm{Cd} \mathrm{kg}^{-1}$ soil) for alleviating the toxicity of Cd to L. perenne. Mainly focused on the effects of AMF on plant growth, nutrition accumulation, photosynthetic characteristics, and antioxidant activities of L. perenne grown in different $\mathrm{Cd}$-added soils. The results of this study will provide new insights into the mechanism of $\mathrm{Cd}$ phytotoxicity alleviation in associate with AM inoculation.

\section{Methods and materials}

\section{Experimental design}

The experiment was designed as a $4 \times 2$ factorial treatments of $\mathrm{Cd}$ level and AMF inoculation organized in a completely randomized design with three replications. Treatments consisted of full factorial combinations of four Cd levels $(0,30,90$ and $180 \mathrm{mg} \mathrm{kg}^{-1}$ ) applied as $3 \mathrm{CdSO}_{4} \cdot 8 \mathrm{H}_{2} \mathrm{O}$, two $\mathrm{AMF}$ treatments (inoculated and noninoculated) in soils planted with ryegrass under greenhouse conditions. The average day and night temperatures were maintained at $25^{\circ} \mathrm{C}$ and $23^{\circ} \mathrm{C}$, respectively, and a $12 \mathrm{~h}$ photoperiod with a light intensity $400 \mu \mathrm{mol} \mathrm{m} \mathrm{m}^{-1}$. The relative humidity was $75 \%$.

\section{Soil preparation}

A sandy loam soil from the $20-30 \mathrm{~cm}$ layer was collected from in forestry station, Northeast Forestry University of Heilongjiang province (latitude, $126^{\circ} 63^{\prime} \mathrm{N}$; longitude, $45^{\circ} 72^{\prime} \mathrm{E}$, northeast China). It was air-dried, sieved ( $2 \mathrm{~mm}$ mesh) and stored at $25^{\circ} \mathrm{C}$ before use. The soil was steam-sterilized $\left(121^{\circ} \mathrm{C}\right.$ for $\left.2 \mathrm{~h}\right)$ by autoclaving to eliminate indigenous mycorrhizal propagules and pathogens, and more specifically to eliminate the influence of 
the AM fungal species used. The soils were artificially contaminated with $3 \mathrm{CdSO}_{4} \cdot 8 \mathrm{H}_{2} \mathrm{O}$ at the following rates: 0 (control), 30, 90 and $180 \mathrm{mg} \mathrm{Cd} \mathrm{kg}^{-1}$. Deionized water was added to the soils to achieve moisture content of $60-70 \%$ of field capacity. To ensure even distribution of $\mathrm{Cd}$, soils were thoroughly mixed while adding $3 \mathrm{CdSO}_{4} \cdot 8 \mathrm{H}_{2} \mathrm{O}$ and water. The soils were incubated at room temperature (about $20 \pm 5^{\circ} \mathrm{C}$ ) for one month to achieve an equilibrium condition, and to lower the effects of soil preparation and disturbance.

\section{Mycorrhiza inoculum and host plants}

The AM fungal inoculum ( $G$. mosseae) was propagated using Trifolium pretense L. as host plants, and the inoculum was the mixture of spores, hyphae, colonized root fragments and substrates. Approximately $50 \mathrm{~g}$ of each AM fungal inoculum was added to $1 \mathrm{~kg}$ sterilized soils. Seeds of ryegrass (Lolium perenne L.) were surface sterilized in a $10 \% \mathrm{v} / \mathrm{v}$ solution of $\mathrm{H}_{2} \mathrm{O}_{2}$ for 10 min, washed in sterilized distilled water and were germinated on wet filter paper in Petri dishes. Two days later, the ryegrass seedlings were selected for uniformity and transplanted into plastic pots. 20 seedlings were transplanted into each pot $(12 \mathrm{~cm} \times 15 \mathrm{~cm})$. Seedlings in pots were irrigated every second day until water drained from the bottom of the pot. After 2 weeks, the cultivated seedlings reached a height of $10 \mathrm{~cm}$, they were thinned a density of 10 plants pot $^{-1}$ and supplied with $1 / 2$ Hoagland's solution every week.

\section{Estimation of mycorrhizal infection rate}

The mycorrhizal infection rate was determined by trypanblue staining (McGonigle et al., 1999). After dyeing, the mycorrhizal infection rate was determined by the modified cross method under the microscope.

$$
\text { Mycorrhizal infection rate }(\%)=\frac{\text { the number of root segments forming clumps }}{\text { the number of measured root segments }} 100
$$

\section{Estimation of root vigor}

Roots were sampled from each treatment (three replicates) were taken. The mixture of roots and soil was placed in a polythene bag and washed with tap water. The roots were carefully refrigerated for further testing. The root vigor was determined using the TTC method (Zhang, 1990).

\section{Estimation of gas exchange}

Net photosynthesis $\left(P_{\mathrm{n}}\right)$, stomatal conductance $\left(G_{\mathrm{s}}\right)$, transpiration rate $\left(T_{\mathrm{r}}\right)$ and intercellular $\mathrm{CO}_{2}$ concentration $\left(C_{\mathrm{i}}\right)$ were measured on expanded leaves. Photosynthetic rate measured at $400 \mu \mathrm{mol} \mathrm{m} \mathrm{m}^{-2} \mathrm{~s}^{-1} \mathrm{CO} 2$ under $800 \mu \mathrm{mol} \mathrm{m} \mathrm{m}^{-2} \mathrm{~s}^{-1}$ PFD was used to calculate photorespiration with a portable photosynthetic system (CIRAS 1, PP systems, UK).

\section{Antioxidant enzymes assays}

SOD activity was measured according to the method of Wang et al. (1990). Fresh tissues $(0.2 \mathrm{~g})$ were ground to a fine powder in liquid $\mathrm{N}_{2}$ then homogenized in $2 \mathrm{~mL}$ of phosphate buffer ( $\mathrm{pH} 7.8)$. The reaction mixture was comprised of $50 \mathrm{mM}$ phosphate buffer ( $\mathrm{pH} 7.8$ ), $130 \mathrm{mM}$ methionine, $750 \mu \mathrm{M}$ nitro-bluetetrazolium, $100 \mu \mathrm{M}$ EDTA- 
$\mathrm{Na}_{2}, 100 \mu \mathrm{M}$ EDTA, $100 \mu \mathrm{M}$ riboflavin, and $0.1 \mathrm{ml}$ of enzyme extract in a final volume of $4 \mathrm{ml}$. There action mixture was incubated for $30 \mathrm{~min}$ under $4000 \mathrm{Lx}$, and absorbance was determined at $560 \mathrm{~nm}$. Catalase (CAT) activity was measured at $25^{\circ} \mathrm{C}$ previously according to the method of Paglia and Valentine (1987) that used hydrogen peroxide as substrate and one unit of catalase was defined as the rate constant of the first order reaction $(\mathrm{k})$.

\section{Measurements of lipid peroxidation}

MDA content was measured following the method of Zhang et al. (1990). Fresh tissues $(0.2 \mathrm{~g})$ were ground to a fine powder in liquid $\mathrm{N}_{2}$ then homogenized in $2 \mathrm{~mL}$ of $10 \%$ trichloroacetic acid (TCA). The mixture was centrifuged at 10,000 r/min for 10 min. For every $2 \mathrm{~mL}$ of the supernatant, $2 \mathrm{~mL}$ of $0.6 \% 2$-thiobarbituric acid (TBA) was mixed. The mixture was incubated at $100^{\circ} \mathrm{C}$ for $15 \mathrm{~min}$ and then transferred into an ice bath to stop the reaction. The tubes were centrifuged at 10,000 r/min for $10 \mathrm{~min}$ and the absorbance of the resulting supernatant was measured at 450, 532 and $600 \mathrm{~nm}$. The concentration of MDA (IM) in the solution was estimated according to the following formula:

$$
M D A \text { concentration }=6.45\left(\mathrm{~A}_{532}-\mathrm{A}_{600}\right)-0.56 \mathrm{~A}_{450}
$$

where $A_{450}, A_{532}$ and $A_{600}$ were represent wavelength measured at 450, 532 and $600 \mathrm{~nm}$.

\section{Measurements of plant growth and biomass}

The middle growth stage was 45 days after sowing. Fresh plants were collected from each pot after plant establishment at the middle growth stage. The 10 plants were collected and rinsed twice with distilled water, and subsequently, the growth parameters (plant height, root length, root/shoot ratio, aboveground, underground, and total biomass per plant) were measured. Plant height was determined with meter rule $(\mathrm{cm})$ from the base of the plant (above the ground level) to the apical region of the leaf. The root length (the longest root) was also obtained using meter rule $(\mathrm{cm})$. Aboveground, underground, and total biomass were weighted after drying the plant samples in a hot air oven at $60^{\circ} \mathrm{C}$ using a constant weight. Root/shoot ratio $=$ Underground biomass/aboveground biomass.

\section{Statistical analysis}

Statistical analysis was performed using the SPSS 17.0 program. The data were analyzed by analysis of variance (ANOVA), where means and standard derivations were calculated for the three replicates. To detect the statistical significance of differences $(P<0.05)$ among $\mathrm{Cd}$ levels, the Tukey test was performed. T-test was performed to detect the statistical significance of differences between non-inoculated and inoculated with AM fungi treatments. 


\section{Results}

\section{Mycorrhizal infection rates}

Mycorrhizal infection rate of G. mosseae to the root of ryegrass was observed in different Cd-contaminated soils (Fig. 1). The rates of mycorrhiza infection were generally reduced (from $69 \%$ to $43 \%$ ) in the presence of $\mathrm{Cd}(P<0.05)$. The rates of mycorrhiza infection in 30,90 and $180 \mathrm{mg} \mathrm{Cd} \mathrm{kg}^{-1}$ soils were significantly decreased by $16.14 \%, 24.93 \%$ and $58.45 \%$, respectively, compared with Cd-uncontaminated soil.

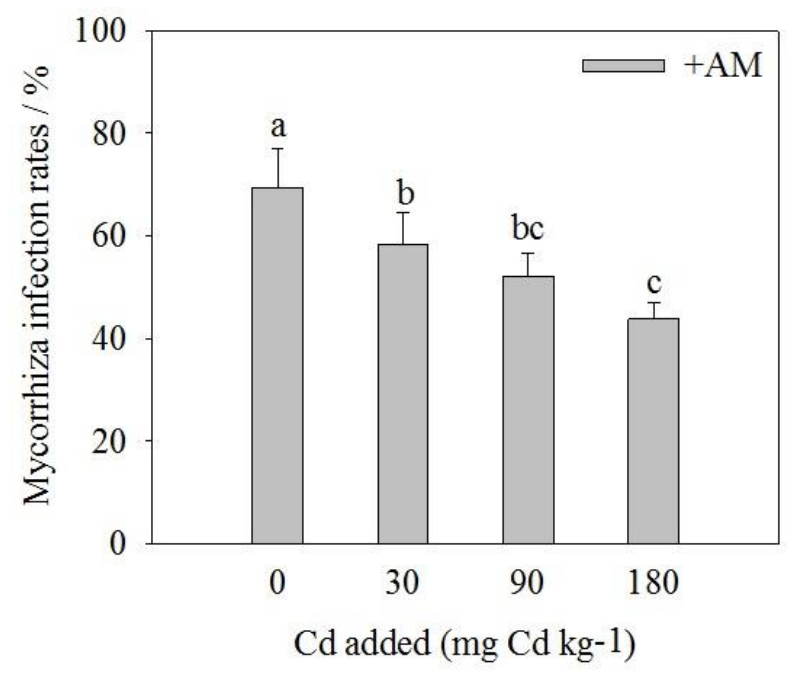

Figure 1. Mycorrhiza infection rates of L. perenne inoculated with $G$. mosseae with increasing Cd level. Abbreviations: $+A M$, inoculated with AMF. Values shown are averages, calculated using 3 replicates for each treatment ( \pm s.d. of the mean). Different letters indicate significant differences at $P<0.05$

\section{Root vigor}

The two-way interaction between $\mathrm{Cd}$ and AMF factors was significant for root vigor $(P<0.05)$ (Fig. 2). There were significant decreases in root vigor for the plants exposed to $\mathrm{Cd}$ compared with $\mathrm{Cd}$-uncontaminated plants. Root vigor was negatively affected by $\mathrm{Cd}$, decreasing with rising the $\mathrm{Cd}$ level in both $G$. mosseae-inoculated and without inoculated plants, but without significant when added at 30 and $90 \mathrm{mg} \mathrm{Cd} \mathrm{kg}^{-1}$ in G. mosseae-inoculated soils and at 90 and $180 \mathrm{mg} \mathrm{Cd} \mathrm{kg}^{-1}$ in without inoculated soils, respectively. G. mosseae inoculation significantly increased root vigor compared with non-inoculated soil at 0,90 and $180 \mathrm{Cd} \mathrm{kg}^{-1}$ levels. Compared to non-inoculated plants, root vigor increased by $43.27 \%, 70.56 \%$ and $55.33 \%$ for $G$. mosseae-inoculated plants added with 0,90 and $180 \mathrm{mg} \mathrm{Cd} \mathrm{kg}^{-1}$, respectively.

\section{Photosynthetic characteristic}

Net photosynthetic rate $\left(P_{\mathrm{n}}\right)$, stomatal conductance $\left(G_{\mathrm{s}}\right)$, transpiration rate $\left(T_{\mathrm{r}}\right)$ and intercellular $\mathrm{CO}_{2}$ concentration $\left(C_{\mathrm{i}}\right)$ were presented in Table 1. The G. mosseae inoculation had higher $T_{\mathrm{r}}$ and $P_{\mathrm{n}}$ than non-inoculated treatments, indicating AMF alleviated Cd-inducted photosynthetic inhibition of ryegrass leaves. At the highest $\mathrm{Cd}$ level, $P_{\mathrm{n}}, G_{\mathrm{s}}$, and $T_{\mathrm{r}}$ of $G$. mosseae inoculated plants were increased by $54.91 \%(P<0.05)$, $37.79 \%(P<0.05)$ and $10.06 \%(P>0.05)$, respectively, in comparison to non-inoculated 


$$
\text { - } 704 \text { - }
$$

plants. Photosynthetic characteristics of ryegrass were sensitive to $\mathrm{Cd}$ addition in noninoculated plants. In general, $P_{\mathrm{n}}$ decreased with increasing Cd levels in non-inoculated plants. The decrease of $G_{\mathrm{s}}$ in Cd-contaminated plants was accompanied with those of $T_{\mathrm{r}}$, but at different extents among treatments. On the contrary, the increase of $C_{\mathrm{i}}$ in $180 \mathrm{mg}$ $\mathrm{Cd} \mathrm{kg}^{-1}$ treatment was of $8.98 \%(P>0.05)$ if compared to the $90 \mathrm{mg} \mathrm{Cd} \mathrm{kg}^{-1}$ treatment.

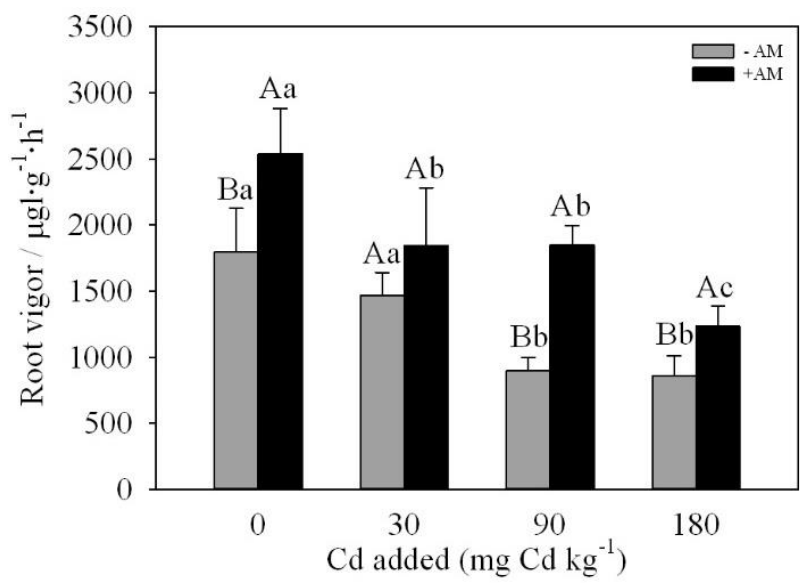

Figure 2. Root vigor of L. perenne inoculated with $G$. mosseae with increasing Cd level. Abbreviations: $-A M$, non-inoculated with arbuscular mycorrhizal fungi $(A M F) ;+A M$, inoculated with AMF. Values shown are averages, calculated using 3 replicates for each treatment ( \pm s.d. of the mean). Different lowercase letters are significantly difference $(P<0.05)$ among $C d$ levels by the Tukey test. Different uppercase letters are significantly difference $(P<0.05)$ between non-inoculated and inoculated with AM fungi treatments by the t-test

Table 1. Gas exchange parameters of ryegrass leaves inoculated with G. mosseae with increasing Cd level

\begin{tabular}{|c|c|c|c|c|c|c|}
\hline Treatment & \multicolumn{2}{|c|}{ AM fungi } & \multirow{2}{*}{$\begin{array}{l}\text { Mean } \\
(\mathrm{Cd})\end{array}$} & \multicolumn{2}{|c|}{ AM fungi } & \multirow{2}{*}{$\begin{array}{l}\text { Mean } \\
(\mathrm{Cd})\end{array}$} \\
\hline $\begin{array}{l}\text { Cd added } \\
(\mathrm{mg} \mathrm{kg}-1)\end{array}$ & $-A M$ & $+\mathrm{AM}$ & & $-\mathrm{AM}$ & $+\mathrm{AM}$ & \\
\hline & \multicolumn{2}{|c|}{$\begin{array}{l}\text { Net photosynthetic rate } \\
\left(\mu \mathrm{mol} \mathrm{m} \mathbf{m}^{-2} \mathrm{~s}^{-1}\right)\end{array}$} & & \multicolumn{2}{|c|}{ 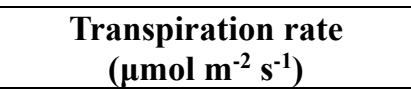 } & \\
\hline 0 & $3.01 \mathrm{~A}$ & $3.44 \mathrm{~A}$ & $3.13 \mathrm{~A}$ & $0.88 \mathrm{~A}$ & $1.17 \mathrm{~A}$ & $1.05 \mathrm{~A}$ \\
\hline 30 & $2.62 \mathrm{AB}$ & $2.91 \mathrm{~A}$ & $2.67 \mathrm{~A}$ & $0.87 \mathrm{~A}$ & $1.04 \mathrm{AB}$ & $0.95 \mathrm{~A}$ \\
\hline 90 & $2.21 \mathrm{AB}$ & $2.83 \mathrm{~A}$ & $2.42 \mathrm{~A}$ & $0.80 \mathrm{~A}$ & $0.87 \mathrm{~B}$ & $0.82 \mathrm{~A}$ \\
\hline 180 & $1.73 \mathrm{bB}$ & $2.68 \mathrm{aA}$ & $2.11 \mathrm{~A}$ & $0.74 \mathrm{~A}$ & $0.89 \mathrm{~B}$ & $0.76 \mathrm{~A}$ \\
\hline \multirow[t]{2}{*}{$\begin{array}{c}\text { Mean } \\
\text { (AM fungi) }\end{array}$} & $2.39 \mathrm{~b}$ & $2.97 \mathrm{a}$ & & $0.82 \mathrm{~b}$ & $0.99 \mathrm{a}$ & \\
\hline & \multicolumn{2}{|c|}{$\begin{array}{c}\text { Stomatal conductance } \\
\left(\mu \mathrm{mol} \mathrm{m^{-2 }} \mathbf{s}^{-1}\right)\end{array}$} & & \multicolumn{2}{|c|}{$\begin{array}{c}\text { Intercellular } \mathrm{CO}_{2} \\
\text { concentration }\left(\mu \mathrm{mol} \mathrm{m}^{-2} \mathbf{s}^{-1}\right)\end{array}$} & \\
\hline 0 & $49.81 \mathrm{~A}$ & $56.90 \mathrm{~A}$ & $55.35 \mathrm{~A}$ & $280.7 \mathrm{~A}$ & $301.3 \mathrm{~A}$ & $291.00 \mathrm{~A}$ \\
\hline 30 & $40.12 \mathrm{~A}$ & $47.5 \mathrm{AB}$ & $45.80 \mathrm{AB}$ & $262.8 \mathrm{~A}$ & $291.9 \mathrm{~A}$ & $277.35 \mathrm{~A}$ \\
\hline 90 & $36.39 \mathrm{AB}$ & $38.12 \mathrm{BC}$ & $39.26 \mathrm{AB}$ & $247.8 \mathrm{~A}$ & $281.8 \mathrm{~A}$ & $264.80 \mathrm{~A}$ \\
\hline 180 & $23.10 \mathrm{~B}$ & $36.21 \mathrm{C}$ & $30.15 \mathrm{~B}$ & $265.9 \mathrm{~A}$ & $249.3 \mathrm{~A}$ & $257.60 \mathrm{~A}$ \\
\hline $\begin{array}{c}\text { Mean } \\
\text { (AM fungi) }\end{array}$ & $37.35 \mathrm{a}$ & $44.68 \mathrm{a}$ & & $264.30 \mathrm{a}$ & $281.08 \mathrm{a}$ & \\
\hline
\end{tabular}

Which each row, mean values $(\mathrm{n}=3)$ with the different lowercase letter are significantly difference $(\mathrm{P}<0.05)$ among AM fungi treatments by the Tukey test. Within each column, mean values $(\mathrm{n}=3)$ with the different uppercase letter are significantly difference $(\mathrm{P}<0.05)$ among $\mathrm{Cd}$ levels by the Tukey test 


\section{Antioxidant activity}

The enhanced SOD and CAT activities were observed for the plants exposed to Cd compared with the control (Fig. 3). SOD activity increased linearly with Cd addition levels, and no significant difference was found between $\mathrm{Cd}$ addition levels of 90 and $180 \mathrm{mg} \mathrm{kg}^{-1}(P>0.05)$. The maximum SOD activity was recorded at $180 \mathrm{mg} \mathrm{Cd} \mathrm{kg}^{-1}$ in both $G$. mosseae-inoculated and without inoculated plants $\left(0.69\right.$ and $0.67 \mathrm{U} \mathrm{mg}^{-1} \mathrm{FW}^{-1}$, respectively). There was no significant difference in SOD activity between $G$. mosseaeinoculated and without inoculated plants under the same $\mathrm{Cd}$ concentration $(P>0.05)$. CAT activity also increased linearly with increasing Cd levels, whereas, a decline in CAT activity with an increase in $180 \mathrm{mg} \mathrm{Cd} \mathrm{kg}^{-1}$ level was observed.

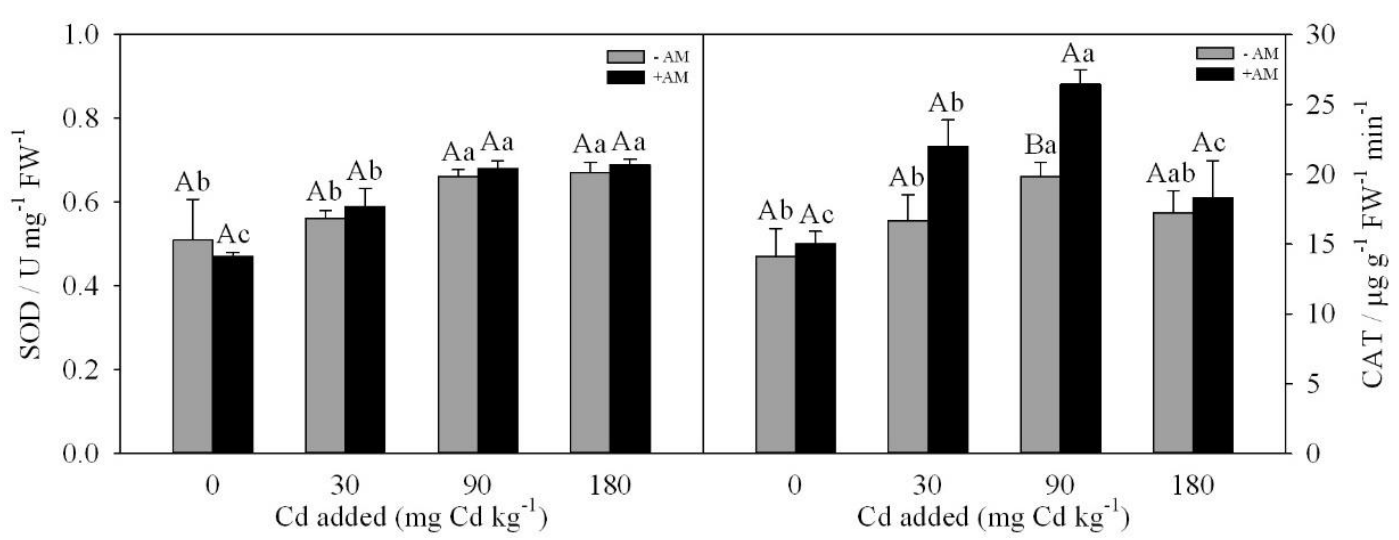

Figure 3. Antioxidative enzyme activities of L. perenne L. inoculated with $G$. mosseae with increasing Cd level. Abbreviations:-AM, non-inoculated with arbuscular mycorrhizal fungi $(A M F) ;+A M$, inoculated with AMF. Values shown are averages, calculated using 3 replicates for each treatment ( \pm s.d. of the mean). Different lowercase letters are significantly difference $(P<0.05)$ among $C d$ levels by the Tukey test. Different uppercase letters are significantly difference $(P<0.05)$ between non-inoculated and inoculated with AM fungi treatments by the t-test

CAT activity of G. mosseae-inoculated and non-inoculated plants showed the same change trend, first increased and then decreased. But the increase range of inoculated was higher than that of non-inoculated plants. The CAT activity was different among different Cd pollution concentrations in both G. mosseae-inoculated and non-inoculated plants. There was no significant difference in CAT activity between inoculated and noninoculated plants under 0 and $30 \mathrm{Cd} \mathrm{kg}^{-1}$ concentration. CAT activity was the highest in both inoculated and non-inoculated plants under $90 \mathrm{Cd} \mathrm{kg}^{-1}$ concentration, and the CAT activity of inoculated plants increased by $29.6 \%$ compared with that of non-inoculated plants at this concentration $(P<0.05)$. While the CAT activity of the inoculated and noninoculated plants decreased under $120 \mathrm{Cd} \mathrm{kg}^{-1}$ concentrations, but it was slightly higher than that of the control. There was no significant difference in CAT activity between G. mosseae-inoculated and without inoculated plants under $120 \mathrm{Cd} \mathrm{kg}^{-1}$ concentration $(P>0.05)$.

\section{Lipid peroxidation}

The effect of $\mathrm{Cd}$ and AMF on MDA content is shown in Fig. 4. There were significant increases in MDA content for the plants exposed to $\mathrm{Cd}$ compared with $\mathrm{Cd}$ - 
uncontaminated plants $(P<0.05)$. Whether inoculated or not, MDA content increased linearly with increasing $\mathrm{Cd}$ levels. No-inoculated plants had significantly higher MDA content than plants inoculated with $G$. mosseae at all $\mathrm{Cd}$ levels $(P<0.05)$. Thus, decreased MDA indicated that AMF relieved the damage of $\mathrm{Cd}$ to cell membrane.

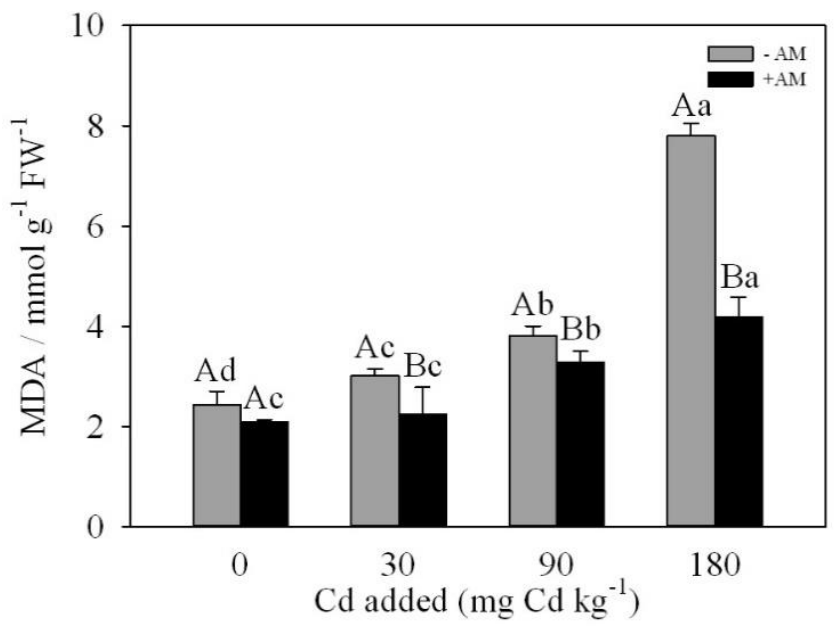

Figure 4. MDA content of L. perenne L. inoculated with G. mosseae with increasing Cd level. Abbreviations: $-A M$, non-inoculated with arbuscular mycorrhizal fungi $(A M F) ;+A M$, inoculated with AMF. Values shown are averages, calculated using 3 replicates for each treatment ( \pm s.d. of the mean). Different lowercase letters are significantly difference $(P<0.05)$ among $C d$ levels by the Tukey test. Different uppercase letters are significantly difference $(P<0.05)$ between non-inoculated and inoculated with AM fungi treatments by the $t$-test

\section{Plant growth and biomass}

Results describing plant height, root length, root/shoot ratio, aboveground biomass, underground biomass and total biomass for different treatments are presented in Table 2. Plant growth was influenced by $\mathrm{Cd}$ level. Whether $G$. mosseae inoculated or not, decreasing plant height, root length, and biomass (underground and aboveground) were observed with in high Cd levels (Table 2). Obviously, high Cd levels inhibited ryegrass growth. When compared to Cd-uncontaminated plants, $\mathrm{Cd}$ addition decreased plant height, root length, aboveground biomass and underground biomass by $30.67 \%, 36.51 \%$, $19.31 \%$ and $30.46 \%$ for G. mosseae inoculated treatments and $18.72 \%, 45.58 \%, 18.23 \%$ and $29.98 \%$ for non-inoculated treatments at $\mathrm{Cd}$ addition levels of $180 \mathrm{mg} \mathrm{kg}$, respectively. At the low Cd level $\left(30 \mathrm{mg} \mathrm{kg}^{-1}\right), \mathrm{Cd}$ stress had no significant effect on aboveground traits (plant height and aboveground biomass), but significant decrease underground traits (root length and underground biomass). Therefore, low soil Cd level increased the root/shoot ratio of ryegrass. The application of AMF alleviated the inhibitory effect of $\mathrm{Cd}$ on ryegrass growth traits (Table 2). At the highest $\mathrm{Cd}$ level, plant height, root length, aboveground, underground and total biomasses of $G$. mosseae inoculated plants were increased by $16.46 \%(P>0.05), 18.60 \%(P<0.05), 23.33 \%$ $(P<0.05), 22.86 \%(P<0.05)$ and $24 \%(P<0.05)$, respectively as compared to the control plants. In generally, inoculation with $G$. mosseae had no effect on root/shoot ratio in different Cd levels. 
Table 2. Growth characteristics of L. perenne inoculated with G. mosseae with increasing $C d$ level

\begin{tabular}{|c|c|c|c|c|c|c|}
\hline \multirow{2}{*}{$\begin{array}{l}\text { Treatment } \\
\text { Cd added } \\
\text { (mg kg-1) }\end{array}$} & \multicolumn{2}{|c|}{ AM fungi } & \multirow[b]{2}{*}{ Mean $(\mathrm{Cd})$} & \multicolumn{2}{|c|}{ AM fungi } & \multirow[b]{2}{*}{ Mean $(\mathrm{Cd})$} \\
\hline & $-\mathrm{AM}$ & $+\mathrm{AM}$ & & $-\mathrm{AM}$ & $+\mathrm{AM}$ & \\
\hline & \multicolumn{2}{|c|}{ Plant height (cm) } & & \multicolumn{2}{|c|}{ Root length (cm) } & \\
\hline 0 & $20.89 \mathrm{AB}$ & $25.76 \mathrm{~A}$ & 23.33 & $14.67 \mathrm{~A}$ & $16.87 \mathrm{~A}$ & 15.77 \\
\hline 30 & $21.67 \mathrm{~A}$ & $27.11 \mathrm{~A}$ & 24.39 & $12.37 \mathrm{~B}$ & $13.89 \mathrm{~B}$ & 13.13 \\
\hline 90 & $20.03 \mathrm{AB}$ & $24.23 \mathrm{~A}$ & 22.13 & $12.02 \mathrm{~B}$ & $12.55 \mathrm{C}$ & 12.29 \\
\hline 180 & $16.98 \mathrm{~B}$ & $17.86 \mathrm{~B}$ & 17.42 & $7.69 \mathrm{C}$ & $10.71 \mathrm{D}$ & 9.2 \\
\hline \multirow[t]{2}{*}{$\begin{array}{c}\text { Mean } \\
\text { (AM fungi) }\end{array}$} & $19.89 b$ & $23.74 \mathrm{a}$ & & 11.69 & 13.51 & \\
\hline & \multicolumn{2}{|c|}{ Root/shoot ratio } & & \multicolumn{2}{|c|}{ Aboveground biomass (g) } & \\
\hline 0 & $0.817 \mathrm{~B}$ & $0.832 \mathrm{~B}$ & 0.825 & $0.0417 \mathrm{~A}$ & $0.0523 \mathrm{~A}$ & 0.0470 \\
\hline 30 & $0.868 \mathrm{~A}$ & $0.908 \mathrm{~A}$ & 0.888 & $0.0382 \mathrm{AB}$ & $0.0522 \mathrm{~A}$ & 0.0452 \\
\hline 90 & $0.820 \mathrm{~B}$ & $0.841 \mathrm{~B}$ & 0.831 & $0.0376 \mathrm{AB}$ & $0.0461 \mathrm{~B}$ & 0.0419 \\
\hline 180 & $0.720 \mathrm{C}$ & $0.725 \mathrm{C}$ & 0.723 & $0.0341 \mathrm{~B}$ & $0.0422 \mathrm{~B}$ & 0.0382 \\
\hline \multirow[t]{2}{*}{$\begin{array}{c}\text { Mean } \\
\text { (AM fungi) }\end{array}$} & 0.806 & 0.827 & & 0.0379 & 0.0482 & \\
\hline & \multicolumn{2}{|c|}{ Underground biomass (g) } & & \multicolumn{2}{|c|}{ Total biomass (g) } & \\
\hline 0 & $0.0348 \mathrm{~A}$ & $0.0447 \mathrm{~B}$ & 0.0398 & $0.0740 \mathrm{~A}$ & $0.0970 \mathrm{AB}$ & 0.0855 \\
\hline 30 & $0.0342 \mathrm{~A}$ & $0.0510 \mathrm{~A}$ & 0.0426 & $0.0724 \mathrm{~A}$ & $0.1032 \mathrm{~A}$ & 0.0878 \\
\hline 90 & $0.031 \mathrm{~A}$ & $0.0388 \mathrm{C}$ & 0.0349 & $0.0686 \mathrm{AB}$ & $0.0849 \mathrm{BC}$ & 0.0768 \\
\hline 180 & $0.0242 \mathrm{~B}$ & $0.0313 \mathrm{D}$ & 0.0278 & $0.0600 \mathrm{~B}$ & $0.0735 \mathrm{C}$ & 0.0668 \\
\hline $\begin{array}{c}\text { Mean } \\
\text { (AM fungi) }\end{array}$ & 0.0311 & 0.0414 & & 0.0688 & 0.0897 & \\
\hline
\end{tabular}

Which each row, mean values $(\mathrm{n}=10)$ with the different lowercase letter are significantly difference $(\mathrm{P}<0.05)$ among AM fungi treatments by the Tukey test. Within each column, mean values $(\mathrm{n}=3)$ with the different uppercase letter are significantly difference $(\mathrm{P}<0.05)$ among $\mathrm{Cd}$ levels by the Tukey test

\section{Plant $N$ and $P$ uptake}

Plant $\mathrm{N}$ and $\mathrm{P}$ uptake in ryegrass plants decreased with $\mathrm{Cd}$ addition, especially in

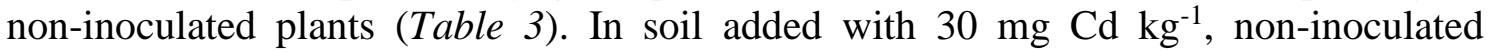
controls had the highest $\mathrm{P}$ content in leaves. However, $\mathrm{Cd}$ tress had no significant influence on P content in leaves colonized by $G$. mosseae. In all Cd treatments, the $G$. mosseae inoculation had profound effects on $\mathrm{N}$ and $\mathrm{P}$ accumulation in leave and root. Overall, G. mosseae inoculation increased $\mathrm{N}$ and $\mathrm{P}$ contents in leaves and roots. In soil added with 30 and $180 \mathrm{mg} \mathrm{Cd} \mathrm{kg}{ }^{-1}$, N content of roots colonized by G. mosseae was significantly higher than that of without inoculation $(P<0.05)$. However, N content of leaves colonized by $G$. mosseae were significantly higher than that of without inoculation in low $\mathrm{Cd}$ level (30 and $\left.90 \mathrm{mg} \mathrm{Cd} \mathrm{kg}^{-1}\right)(P<0.05)$. $\mathrm{P}$ content in leaves and roots of G. mosseae-inoculated plants was significantly higher than the non-inoculated plants at the same $\mathrm{Cd}$ addition level except $90 \mathrm{mg} \mathrm{Cd} \mathrm{kg}^{-1}$ level treatment $(P<0.05)$. Therefore, not all the $\mathrm{N}$ and $\mathrm{P}$ accumulation in both leave and root of $G$. mosseae inoculated plants were significantly higher than those of non-inoculated controls in $\mathrm{Cd}$ contaminated soil. 
Table 3. $N$ and $P$ concentrations of ryegrass leave and root inoculated with $G$. mosseae with increasing Cd level

\begin{tabular}{|c|c|c|c|c|c|c|}
\hline \multirow{2}{*}{$\begin{array}{l}\text { Treatment } \\
\text { Cd added } \\
\text { (mg kg-1) }\end{array}$} & \multicolumn{2}{|c|}{ AM fungi } & \multirow[b]{2}{*}{ Mean $(\mathrm{Cd})$} & \multicolumn{2}{|c|}{ AM fungi } & \multirow[b]{2}{*}{ Mean $(\mathrm{Cd})$} \\
\hline & -AM & $+\mathrm{AM}$ & & $-\mathrm{AM}$ & $+\mathrm{AM}$ & \\
\hline & \multicolumn{2}{|c|}{ Root $\mathrm{N}$ content $\left(\mathrm{g} \mathrm{kg}^{-1}\right)$} & & \multicolumn{2}{|c|}{ Leave $N$ content $\left(\mathrm{g} \mathrm{kg}^{-1}\right)$} & \\
\hline 0 & $0.60 \mathrm{aA}$ & $0.63 \mathrm{aA}$ & $0.62 \mathrm{~A}$ & $1.15 \mathrm{aA}$ & $1.26 \mathrm{aA}$ & $1.21 \mathrm{~A}$ \\
\hline 30 & $0.57 \mathrm{bA}$ & $0.69 \mathrm{aA}$ & $0.63 \mathrm{~A}$ & $0.96 \mathrm{bAB}$ & $1.22 \mathrm{aA}$ & $1.09 \mathrm{~A}$ \\
\hline 90 & $0.51 \mathrm{aB}$ & $0.52 \mathrm{aB}$ & $0.52 \mathrm{~B}$ & $0.81 \mathrm{bB}$ & $0.88 \mathrm{aC}$ & $0.85 \mathrm{~B}$ \\
\hline 180 & $0.32 \mathrm{bC}$ & $0.49 \mathrm{aB}$ & $0.41 \mathrm{C}$ & $0.80 \mathrm{aB}$ & $0.76 \mathrm{aD}$ & $0.78 \mathrm{C}$ \\
\hline \multirow[t]{2}{*}{$\begin{array}{c}\text { Mean } \\
\text { (AM fungi) }\end{array}$} & $0.50 \mathrm{~b}$ & $0.58 \mathrm{a}$ & & $0.93 \mathrm{~b}$ & $1.03 \mathrm{a}$ & \\
\hline & \multicolumn{2}{|c|}{ Root $P$ content $\left(\mathrm{g} \mathrm{kg}^{-1}\right)$} & & \multicolumn{2}{|c|}{ Leave $P$ content $\left(\mathrm{g} \mathrm{kg}^{-1}\right)$} & \\
\hline 0 & $3.29 \mathrm{bA}$ & $4.11 \mathrm{aA}$ & $3.70 \mathrm{~A}$ & $3.22 \mathrm{bB}$ & $4.31 \mathrm{aA}$ & $3.77 \mathrm{~B}$ \\
\hline 30 & $2.48 \mathrm{aB}$ & $2.45 \mathrm{aB}$ & $2.47 \mathrm{~B}$ & $4.25 \mathrm{aA}$ & $4.20 \mathrm{aA}$ & $4.23 \mathrm{~A}$ \\
\hline 90 & $1.80 \mathrm{bC}$ & $2.31 \mathrm{aB}$ & $2.06 \mathrm{C}$ & $3.11 \mathrm{bBC}$ & $4.22 \mathrm{aA}$ & $3.67 \mathrm{~B}$ \\
\hline 180 & $1.75 \mathrm{bC}$ & $2.12 \mathrm{aBC}$ & $1.94 \mathrm{C}$ & $3.26 \mathrm{bB}$ & $4.26 \mathrm{aA}$ & $3.76 \mathrm{~B}$ \\
\hline $\begin{array}{c}\text { Mean } \\
\text { (AM fungi) }\end{array}$ & $2.33 \mathrm{~b}$ & $2.75 \mathrm{a}$ & & $3.46 \mathrm{~b}$ & $4.25 \mathrm{a}$ & \\
\hline
\end{tabular}

Which each row, mean values $(n=3)$ with the different lowercase letter are significantly difference $(\mathrm{P}<0.05)$ among AM fungi treatments by the Tukey test. Within each column, mean values $(\mathrm{n}=3)$ with the different uppercase letter are significantly difference $(\mathrm{P}<0.05)$ among $\mathrm{Cd}$ levels by the Tukey test. $\mathrm{AM}=$ non-mycorrhizal, $+\mathrm{AM}=$ with mycorrhizal

\section{Discussion}

The AM fungal specie (G. mosseae) used in our research successfully colonized ryegrass plants grown in $\mathrm{Cd}$-contaminated soils, indicating that $G$. mosseae is $\mathrm{Cd}$ tolerant and able to maintain an efficient symbiosis with ryegrass root systems even under high $\mathrm{Cd}$ stress. However, Cd contamination decreased ryegrass colonization by $G$. mosseae. Similar findings were found for maize (Chen et al., 2004a), sunflower (Hassan et al., 2013) and other plants (Li et al., 2009). The reduction in root colonization rate with $\mathrm{Cd}$ addition indicates the toxicity of $\mathrm{Cd}$ for $\mathrm{AM}$ fungal species.

In our study, we found that the rate of mycorrhizal infection inoculated with G. mosseae decreased with the increase of $\mathrm{Cd}$ concentration, but the rate was still as high as $43 \%$ under high concentration of $\mathrm{Cd}\left(180 \mathrm{mg} \mathrm{Cd} \mathrm{kg}^{-1}\right)$. Secondly, compared with the plants of non-inoculated with $G$. mosseae, the inoculated plants improved the root activity at the same $\mathrm{Cd}$ concentration level, indicating that AM fungal has strong tolerance and resistance to $\mathrm{Cd}$ contamination. Gao (2017) showed that low concentration $\mathrm{Cd}$ could promote plant growth, whereas high concentration can inhibit plant growth, which are consistent with our results.

By Cd stress, net photosynthetic rate $(P \mathrm{n})$, stomatal conductance $(G \mathrm{~s})$ and transpiration rate $(T \mathrm{r})$ and intercellular $\mathrm{CO}_{2}$ concentration $(C \mathrm{i})$ of ryegrass leaf are lower, which indicated photosynthetic capacity under $\mathrm{Cd}$ stress were more obvious inhibitory effect. This is related to the effect of Cd stress on photosynthesis by affecting the absorption, reduction and assimilation of $\mathrm{N}, \mathrm{P}, \mathrm{Fe}$ and $\mathrm{Mg}$ related to photosynthesis, reducing pigment content, inhibiting stomatal opening, destroying photosynthetic apparatus, affecting water balance and electron transport (Bishnoi et al., 1993). 
However, the increase in $C \mathrm{i}$ index of non-inoculated $G$. mosseae at high $\mathrm{Cd}$ concentration (180 mg Cd kg $\mathrm{mg}^{-1}$ ) may be due to the decrease in net photosynthetic rate, which reduces the consumption of intercellular $\mathrm{CO}_{2}$ and increases the concentration of intercellular $\mathrm{CO}_{2}$ (Anjum et al., 2016). $P$ n, $G$ s, $T \mathrm{r}$ and $C$ i of ryegrass inoculated with $G$. mosseae alleviated the negative effects of photosynthesis to some extent. Chen (2017) found that under the stress of $\mathrm{Cd}$, AM fungi inoculation restored the photosynthesis of female poplar to a certain extent. This is related to the promotion of host plant nutrient balance and antioxidant capacity by inoculation of AM fungi as well as the increase of host photosynthetic capacity and photochemical efficiency (Li et al., 2016).

MDA has been widely used as an indicator of membrane lipid peroxidation damage. Under the stress of $\mathrm{Cd}$, the balance between the production and clearance of reactive oxygen species is broken, which is likely to cause oxidative damage to cells and excessive accumulation of ROS and inhibit plant growth (Maiti et al., 2012). In this experiment, with the increase of $\mathrm{Cd}$ pollution concentration, MDA content in both inoculated and non-inoculated with G. mosseae plants showed an increased trend, indicating that $\mathrm{Cd}$ stress caused the increase of reactive oxygen species in leaves and promoted the degree of membrane lipid peroxidation in leaves. Under the same concentration of $\mathrm{Cd}$, MDA content in the leaves of the inoculated with G. mosseae was lower than that of the non-inoculation leaves, which alleviated the $\mathrm{Cd}$ toxicity to a certain extent, cleared the excess reactive oxygen species, and reduced the damage to the cell membrane. SOD and CAT can effectively remove harmful substances produced under the stress of $\mathrm{Cd}$, such as superoxide anions, and help to keep ROS at controlled level and reduce stress state (Ning and Yan, 2019). In this study, the SOD concentration of plants in the inoculated and non-inoculated with G. mosseae increased with the increase of $\mathrm{Cd}$ concentration, while the content of CAT first increased and then decreased. The results showed that with the increase of $\mathrm{Cd}$ concentration, the accumulation of reactive oxygen radicals led to the increase of CAT activity. The CAT activity of inoculated plants increased more, and the ability of scavenging active oxygen free radical was stronger, which improved the resistance of ryegrass to $\mathrm{Cd}$ pollution. The increase in SOD and CAT activity could possibly be the result of both a direct effect of heavy metal ions and an indirect effect mediated via an increase in levels of superoxide radicals (Chongpraditnun et al., 1992), which could alleviate cell membrane damage. However, the stress of high concentration of Cd $\left(180 \mathrm{mg} \mathrm{kg}^{-1}\right)$ may cause the inactivation of CAT protein, indicating that antioxidant enzymes of plants have certain limits on the clearance of reactive oxygen species. Compared with non-inoculated with G. mosseae, inoculated plants reduced the damage of harmful substances to cells, which could be confirmed by increasing the biomass, plant height, root length and MDA content of ryegrass by inoculated G. mossea.

The plant height and root/shoot ratio of the inoculated and non-inoculated AM fungal plants, and the aboveground, underground and total biomass of the inoculated AM fungal plants first increased and then decreased under low $\mathrm{Cd}$ concentration. Compared with non-inoculated with $G$. mosseae, inoculated plants alleviated Cd pollution and promoted the growth of ryegrass. On the one hand, after mycorrhizal fungi infect the host, the mycorrhizal fungi secrete mucus, polyphosphoric acid, organic acid and the metal chelating peptide formed by plants can adsorb heavy metals in the root, inhibit the $\mathrm{Cd}$ transport to the aboveground part of ryegrass, and reduce the toxicity of $\mathrm{Cd}$ stress to ryegrass (Wang et al., 2010). On the other hand, inoculation of AM fungi can expand the absorption area of roots, improve the absorption ability of ryegrass to nutrients and 
mineral elements, and promote the growth of plants. Meanwhile, AM fungi can produce various growth hormones to promote the growth and development of plant roots. However, with the increase of Cd concentration, the inoculated AM fungi plants were all poisoned by $\mathrm{Cd}$. Zarei (2008b) proved that AM fungi diversity decreased in the soil contaminated by high concentration of zinc. Inoculation of AM fungi improved the tolerance of ryegrass to $\mathrm{Cd}$ stress to some extent, but it was still affected by high concentration of $\mathrm{Cd}$.

Heavy metal pollution tends to adversely affect the nutritional status of plants, mainly due to the inhibition of nutrient uptake. Tanaka and Yano (2010) found that increase in the $\mathrm{N}$ uptake in plants of AM fungi inoculated. Our research showed that plants of inoculated with $G$. mosseae increased the $\mathrm{N}$ and $\mathrm{P}$ contents in roots and leaves compared with the non-inoculated plants under the stress of $\mathrm{Cd}$, which indicated that AM fungi promoted the nutrient uptake of ryegrass. This may be related to the fact that the plants infected by AM fungi changes the composition of soil microbial community, leading to the increase of saprophytes, the acquisition of nitrogen in organic matter, and the promotion of nitrogen uptake by plants (Cuéllar et al., 2015). Cruz (2017) found that plant roots of AM fungi infected changed the configuration of roots and increased the absorption capacity of active root areas, which promoting the absorption of $\mathrm{N}, \mathrm{P}$ and mineral elements. Moreover, in the same Cd level, the content of $\mathrm{N}$ and $\mathrm{P}$ in leaves of inoculated with G. mosseae was higher than that of root. Cui (2019) found that Cd tolerance genotypes reduced $\mathrm{Cd}$ transport to leaves and reduced the toxicity of $\mathrm{Cd}$ to plant leaves by reducing GmHMA18 expression.

\section{Conclusion}

In summary, compared with uncontaminated ryegrass, the growth of inoculated and non-inoculated AM fungi ryegrass was inhibited with the increase of $\mathrm{Cd}$ pollution concentration. Compared with non-inoculation of AM fungi ryegrass, inoculation of AM fungi could improve the resistance and tolerance of ryegrass to $\mathrm{Cd}$ stress, and to a certain extent, restored mycorrhizal activity, plant growth and biomass, photosynthetic physiology, and $\mathrm{N}$ and $\mathrm{P}$ content in roots and leaves. Moreover, the content of SOD and CAT was increased, MDA was decreased, which could alleviate the damage of harmful substances on cells and promote the growth of ryegrass. We propose that AM fungi might potentially be important not only in protecting plants against $\mathrm{Cd}$ toxicity, but also in its bioaccumulation and phytoremediation techniques in these polluted soils.

Acknowledgements. The study was supported by the National Natural Science Foundation of China (41701289), China Postdoctoral Science Foundation (2018M640287).

\section{REFERENCES}

[1] Alguacil, M. M., Torrecillas, E., Caravaca, F., Fernández, D. A., Azcón, R., Roldán, A. (2011): The application of an organic amendment modifies the arbuscular mycorrhizal fungal communities colonizing native seedlings grown in a heavy-metal-polluted soil. Soil Biology \& Biochemistry 43: 1498-1508.

[2] Ali, H., Khan, E., Sajad, M. A. (2013): Phytoremediation of heavy metals-Concepts and applications. - Chemosphere 91: 869-81. 


$$
\text { - } 711 \text { - }
$$

[3] Anjum, S. A., Ashraf, U., Khan, I., Tanveer, M., Saleem, M. F., Wang, L. (2016): Aluminum and Chromium Toxicity in Maize: Implications for Agronomic Attributes, Net Photosynthesis, Physio-Biochemical Oscillations, and Metal Accumulation in Different Plant Parts. - Water Air \& Soil Pollution 227: 326.

[4] Arienzo, M., Adamo, P., Cozzolino, V. (2004): The potential of Lolium perenne for revegetation of contaminated soil from a metallurgical site. - Science of the Total Environment 319: 13-25.

[5] Asgher, M., Khan, M. I., Anjum, N. A., Khan, N. A. (2015): Minimising toxicity of cadmium in plants--role of plant growth regulators. - Protoplasma 252: 399-413.

[6] Augé, R. M., Duan, X., Ebel, R. C., Stodola, A. J. W. (1994): Nonhydraulic signalling of soil drying in mycorrhizal maize. - Planta 193: 74-82.

[7] Bishnoi, N. R., Chugh, L. K., Sawhney, S. K. (1993): Effect of Chromium on Photosynthesis, Respiration and Nitrogen Fixation in Pea (Pisum sativum L.) Seedlings. Journal of Plant Physiology 142: 25-30.

[8] Chen, B. D., Liu, Y., Shen, H., Li, X. L., Christie, P. (2004a): Uptake of cadmium from an experimentally contaminated calcareous soil by arbuscular mycorrhizal maize (Zea mays L.). - Mycorrhiza 14: 347-354.

[9] Chen, B. D., Liu, Y., Shen, H., Li, X. L., Christie, P. (2004b): Uptake of cadmium from an experimentally contaminated calcareous soil by arbuscular mycorrhizal maize (Zea mays L.). - Mycorrhiza 14: 347-54.

[10] Chen, B. D., Zhu, Y. G., Duan, J., Xiao, X. Y., Smith, S. E. (2007): Effects of the arbuscular mycorrhizal fungus Glomus mosseae on growth and metal uptake by four plant species in copper mine tailings. - Environmental Pollution 147: 374-380.

[11] Chen, L. H., Hu, X. W., Yang, W. Q., Wang, X. J., Tan, L. J., Zhang, J. (2017): Effects of arbuscular mycorrhizae fungi inoculation on absorption of $\mathrm{Pb}$ and $\mathrm{Cd}$ in females and males of Populus deltoides when exposed to $\mathrm{Pb}$ and $\mathrm{Cd}$ pollution. - Acta Scientiae Circumstantiae 37: 308-317.

[12] Chongpraditnun, P., Mori, S., Chino, M. (1992): Excess Copper Induces A Cytosolic Cu, Zn-Superoxide Dismutase in Soybean Root. - Plant \& Cell Physiology 33: 239-244.

[13] Cruz, A. F., Oliveira, B. F. D., Pires, M. D. C. (2017): Optimum Level of Nitrogen and Phosphorus to Achieve Better Papaya (Carica papaya var. Solo) Seedlings Growth and Mycorrhizal Colonization. - International Journal of Fruit Science: 1-10.

[14] Cuéllar, A. E., Martinez, L. R., Espinosa, R. R., Cuéllar, E. E. (2015): Nitrogen and arbuscular mycorrhizal fungi (AMF) effect on two commercial sweet potato clones on an inseptisol soil. - Centro Agrícola 42: 39-46.

[15] Cui, G., Ai, S., Chen, K., Wang, X. (2019): Arbuscular mycorrhiza augments cadmium tolerance in soybean by altering accumulation and partitioning of nutrient elements, and related gene expression. - Ecotoxicology and environmental safety 171: 231-239.

[16] Davies, F. T., Puryear, J. D., Newton, R. J., Egilla, J. N., Grossi, J. A. S. (2001): Mycorrhizal fungi enhance accumulation and tolerance of chromium in sunflower (Helianthus annuus). - Journal of Plant Physiology 158: 777-786.

[17] Díaz, G., Azcón-Aguilar, C., Honrubia, M. (1996): Influence of arbuscular mycorrhizae on heavy metal $(\mathrm{Zn}$ and $\mathrm{Pb})$ uptake and growth of Lygeum spartum and Anthyllis cytisoides. - Plant and Soil 180: 241-249.

[18] Duan, N., Yan, M. (2019): Effects of AM fungi on growth and physiological characteristics of Medicago sativa in different composite substrates in coal mining subsidence areas. - Guihaia 39(5): 650-660.

[19] Gao, Y., Liu, B., Song, W. J., Jiang, Y. Y., Lu, M., Wang, K. Y., Yang, X. H. (2017): The effect of Gigaspora rosea on growth and physiological resistance of Nicotiana tabaccum under Cd stress. - Journal of Fungal Research 15(1): 27-32.

[20] Gonzalez-Chavez, C., D'Haen, J., Vangronsveld, J., Dodd, J. C. (2002): Copper sorption and accumulation by the extraradical mycelium of different Glomus spp. (arbuscular mycorrhizal fungi) isolated from the same polluted soil. - Plant \& Soil 240(2): 287-297. 


$$
\text { - } 712 \text { - }
$$

[21] Gonzalez-Chavez, C., Harris, P. J., Dodd, J., Meharg, A. A. (2010): Arbuscular mycorrhizal fungi confer enhanced arsenate resistance on Holcus lanatus. - New Phytologist 155: 163-171.

[22] Hassan, S. E., Hijri, S. A. (2013): Effect of arbuscular mycorrhizal fungi on trace metal uptake by sunflower plants grown on cadmium contaminated soil. - New Biotechnol 30: 780-787.

[23] Hassan, M., Mansoor, S. (2014): Oxidative stress and antioxidant defense mechanism in mung bean seedlings after lead and cadmium treatments. - Turkish Journal of Agriculture \& Forestry 38: 55-61.

[24] Kirkham, M. B. (2006): Cadmium in plants on polluted soils: Effects of soil factors, hyperaccumulation, and amendments. - Geoderma 137: 19-32.

[25] Li, Y., Peng, J., Shi, P., Zhao, B. (2009): The effect of Cd on mycorrhizal development and enzyme activity of Glomus mosseae and Glomus intraradices in Astragalus sinicus L. - Chemosphere 75: 894-899.

[26] Li, M. L., Li, H., Wang, K. R., Shi, L., Liu, J., Zhang, L. (2016): Effect of arbuscular mycorrhizae on the growth, photosynthetic characteristics and cadmium uptake of peanut plant under cadmium stress. - Environmental Chemistry 35: 2344-2352.

[27] Maiti, S., Ghosh, N., Mandal, C., Das, K., Adak, M. K. (2012): Responses of the maize plant to chromium stress with reference to antioxidation activity. - Brazilian Journal of Plant Physiology 24: 203-212.

[28] McGonigle, T. P., Miller, M. H., Evans, D. G. (1990): A new method which gives an objective measure of colonization of roots by vesicular-arbuscular mycorrhizal fungi. New Pgytologist 115: 495-501.

[29] Meng, L., Qiao, M., Arp, H. P. H. (2011): Phytoremediation efficiency of a PAHcontaminated industrial soil using ryegrass, white clover, and celery as mono- and mixed cultures. - Journal of Soils \& Sediments 11: 482-490.

[30] Paglia, D. E., Valentine, W. N. (1987): Studies on the quantitative and qualitative characterization of glutathione peroxidase. - J. Lab. Med. 70: 158-165.

[31] Peralta, J. R., Gardeatorresdey, J. L., Tiemann, K. J., Gomez, E., Arteaga, S., Rascon, E., Parsons, J. G. (2001): Uptake and effects of five heavy metals on seed germination and plant growth in alfalfa (Medicago sativa L.). - Bulletin of Environmental Contamination and Toxicology 66: 727-734.

[32] Pozo, M. J., Cordier, C., Dumas-Gaudot, E., Gianinazzi, S., Barea, J. M., Azcón-Aguilar, C. (2002): Localized versus systemic effect of arbuscular mycorrhizal fungi on defence responses to Phytophthora infection in tomato plants. - J Exp Bot 53: 525-534.

[33] Rajkumar, M., Sandhya, S., Prasad, M. N., Freitas, H. (2012): Perspectives of plantassociated microbes in heavy metal phytoremediation. - Biotechnology Advances 30(15): $62-74$.

[34] Rillig, M. C., Steinberg, P. D. (2002): Glomalin production by an arbuscular mycorrhizal fungus: a mechanism of habitat modification? - Soil Biology \& Biochemistry 34: 13711374.

[35] Schützendübel, A., Nikolova, P., Rudolf, C., Polle, A. (2002): Cadmium and $\mathrm{H}_{2} \mathrm{O}_{2^{-}}$ induced oxidative stress in Populus $\times$ canescens roots. - Plant Physiology \& Biochemistry 40: 577-584.

[36] Shahabivand, S., Maivan, H. Z., Goltapeh, E. M., Sharifi, M., Aliloo, A. A. (2012): The effects of root endophyte and arbuscular mycorrhizal fungi on growth and cadmium accumulation in wheat under cadmium toxicity. - Plant Physiology \& Biochemistry 60: 53-8.

[37] Shetty, K. G., Hetrick, B. A., Schwab, A. P. (1995): Effects of mycorrhizae and fertilizer amendments on zinc tolerance of plants. - Environmental Pollution 88: 307-314.

[38] Shukurov, N., Pen-Mouratov, S., Steinberger, Y. (2005): The impact of the Almalyk Industrial Complex on soil chemical and biological properties. - Environmental Pollution 136(3): 31-40. 
[39] Smith, S. E., Read, D. J. (1997): Mycorrhizal symbioses. - Second edition, Academic Press, London, U.K.

[40] Tanaka, Y., Yano, K. (2010): Nitrogen delivery to maize via mycorrhizal hyphae depends on the form of N supplied. - Plant Cell and Environment 28: 1247-1254.

[41] Turnau, K., Ryszka, P., Gianinazzi-Pearson, V., Tuinen, D. V. (2001): Identification of arbuscular mycorrhizal fungi in soils and roots of plants colonizing zinc wastes in southern Poland. - Mycorrhiza 10: 169-174.

[42] Vodnik, D., Grcman, H., Macek, I., Elteren, J. T., Kovacevic, M. (2008): The contribution of glomalin-related soil protein to $\mathrm{Pb}$ and $\mathrm{Zn}$ sequestration in polluted soil. Science of the Total Environment 392: 130-136.

[43] Wang, M. Y., Xia, R. X., Wang, P. (2010): Effects of arbuscular mycorrhizal fungi on available iron and metals sequestered by glomalin in different rhizospheric soil of Poncirus trifoliata. - Journal of Fujian Agriculture and Forestry University 39: 42-46.

[44] Whitfield, L., Richards, A. J., Rimmer, D. L. (2004): Relationships between soil heavy metal concentration and mycorrhizal colonisation in Thymus polytrichus in northern England. - Mycorrhiza 14: 55-62.

[45] Y1lmaz, D. D., Parlak, K. U. (2011): Changes in proline accumulation and antioxidative enzyme activities in Groenlandia densa under cadmium stress. - Ecological Indicators 11: 417-423.

[46] Yong, Y., Zhang, F. S., Li, H. F., Jiang, R. F. (2009): Accumulation of cadmium in the edible parts of six vegetable species grown in Cd-contaminated soils. - Journal of Environmental Management 90: 1117-1122.

[47] Zarei, M., Koenig, S., Hempel, S., Nekouei, M. K., Savaghebi, G., Buscot, F. (2008a): Community structure of arbuscular mycorrhizal fungi associated to Veronica rechingeri at the Anguran zinc and lead mining region. - Environmental Pollution 156: 1277-1283.

[48] Zarei, M., Saleh-Rastin, N., Jouzani, G. S., Savaghebi, G., Buscot, F. (2008b): Arbuscular mycorrhizal abundance in contaminated soils around a zinc and lead deposit. - European Journal of Soil Biology 44: 381-391.

[49] Zhang, Z. L. (1990): Experimental guidance of plant physiology. - Second edition, Beijing: Higher Education Press 39-160.

[50] Zorrig, W., Khouni, A. E., Ghnaya, T., Davidian, J. C., Abdelly, C., Berthomieu, P. (2013): Lettuce-a species with a high capacity for cadmium (Cd) accumulation and growth stimulation in the presence of low Cd concentrations. - Journal of Horticultural Science \& Biotechnology 88: 72-72. 